\title{
Response of the Asian Sea Bass Lates calcarifer Fingerlings to Different Feeding Rates and Feeding Frequencies Reared in Hyper Saline Condition
}

\author{
A.J. Salama and M.A. Al-Harbi \\ Faculty of Marine Science, King Abdulaziz University, \\ P.O.Box, 80207, Jeddah, 21589, Saudi Arabia
}

\begin{abstract}
This study aimed to develop a suitable feeding program for the Asian sea bass, lates calcarifer fingerlings under supersaline condition by testing different feeding rates (FR) and feeding frequencies (FF). Three feeding rates namely; $1 \%, 2 \%$ and $4 \%$ and three feeding frequencies $1 \mathrm{X}, 2 \mathrm{X}$ and $4 \mathrm{X}$ were used in the study. Results showed that growth after 60 days parameters gave the highest values with $4 \%$ and $4 \mathrm{X}$. FCR increased with increasing FR, while better FCR and PER was achieved with increasing FF. Survival rates in all the feeding rates and frequencies were almost $100 \%$. Significant relationship was recorded between growth, FCR and PER and feeding rates, but not with FF. No significant relationship in both FR and FF with survival rate. Interaction effect of FR and FF was exhibited in all the growth parameters and FCR. All the water quality values obtained were within the safe limits for rearing the Asian sea bass fingerlings.
\end{abstract}

Keywords: Asian sea bass, feeding rates, feeding frequencies, growth, Feed conversion, Survival, water quality.

\section{Introduction}

Aquaculture is rapidly growing in the Kingdom of Saudi Arabia. In the Western Region along the Red Sea coast of Saudi Arabia several species of marine finfish such as groupers, rabbit fish, and the Asian sea bass have been screened for their aquaculture potential (FFC, Ann. Reps. 2000, 2001, 2002 and 2003). The Asian sea bass, Lates calcarifer was found to have a very strong potential for culture along the Red sea coast with salinities ranging from 38 to $42 \%$. 
In the Kingdom of Saudi Arabia pioneering research and development efforts by the Fish Farming Center of the Ministry of Agriculture and Water have resulted in the successful culture of the species from brood stock to grow-out stage under hypersaline condition of the Red Sea water. Results of larval rearing stage yielded survival rates ranging from 20 to $40 \%$ (FFC Ann. Rep. 2003). In the nursery rearing stage survival or recovery rates varied from 25 to $100 \%$ depending on the age of the fingerling and the grading interval (FFC Ann. Rep. 2003). In the grow-out phase after six months from stocking, an average weight of 500 to $700 \mathrm{~g}$ was achieved from an initial weight of 20 to $30 \mathrm{~g}$ with survival rates ranging from 90 to $96 \%$ and an FCR of 1.0 to 1.4 (FFC Ann Rep. 2002). Stocking densities used were 10 and 20 fingerlings $/ \mathrm{m}^{3}$.

Studies on the effect of feeding levels showed that increase feed supply increases growth (Andrew, et al., 2004). Growth is affected by the amount of food consumed and the efficiency of assimilation (Buurma and Diana, 1994). Making food available at an appropriate rate can increase feed efficiency (Lee et al., 2000). Study of Carlos (1988) on bighead carp fry found that the highest feeding rate of 30\% resulted in better growth. Likewise, Shimeno, et al., (1997) found similar trend in common carp. The same pattern had been found also in the growth of catla fry fed different feeding rates (Seenapa and Devaraj, 1991). In grouper grow-out culture in cages, the optimum ration given on alternate days was found to be $5 \%$ yielding the best mean weight, uniform condition factor with time, relatively good survival rate and best feed efficiency (Chua and Teng, 1982). Nour, et al., (1993) also found that increasing feeding rates will result in increased growth performance in mullet fingerlings. Similarly, Silva, et al., (1986) in their study on tilapia fry stated that SGR, FCR and PER was not only affected by feeding frequency but also by ration size. In Asian sea bass nursery, rapidly growing fry of about $0.25 \mathrm{~g}$ generally require as much as $10 \%$ of their weight daily, but as they grow and reach to about $4 \mathrm{~g}$ the ration can be reduced to 5\% (Pillay, 1990). Boonyaratpalin (1997) prepared a feeding table to include feeding rate for small sea bass in which feeding ration ranged from 3.50 to $7.18 \%$.

Feeding frequency on the other hand had been known to affect fish growth and FCR (Grayton and Beamish, 1977, Andrews and Page 1975). 
The influence of feeding frequency on growth has been examined in several species including hybrid sunfish (Wang, et al., 1998), Japanese flounder (Lee et al., 2000), tilapia (Riche, et al., 2004), Australian snapper (Tucker, et al., 2006), tambaqui (Silva, et al., 2007), and cuneate drum (Wang, et al., 2007). Feeding frequency and ration size play a determinant role in regulating feed intake, growth and waste outputs of fish (Silva, et al., 2007; and Wang, et al., 2007). Hashim, et al., (1994) found that more frequent feeding of 4 times resulted in more uniform marketable sized fish. In tilapia fry feeding frequency affected SGR, FCR and FCR. Chua and Teng, (1978) conducted a three month study on the effect of feeding frequency on the growth of young grouper. Optimal growth, good feed conversion and high survival rate were observed in satiation feeding with one feeding every two days.

In Asian sea bass, according to Pillay, (1990) feeding frequency decreases from about $8 \mathrm{X}$ daily for fry weighing less than $1.5 \mathrm{~g}$ to 4 times a day for advanced fry. Boonyaratpalin, (1997) recommended a feeding frequency range of 2 to $3 \mathrm{X}$ daily for the species from nursery to grow-out stages.

As experienced at the Fish Farming Center with the high number of fry, cannibalism is considered a major problem during nursery rearing as the fry and fingerling sizes varies greatly. Cannibalism can be a major cause of mortalities and losses during the nursery phase and during the early grow-out (Tattanon and Tiensonggrusmee, 1984, Kungvankij, et al., 1986, NICA, 1986, Parazo, et al., 1991). Sea bass will cannibalize fish up to $61-67 \%$ of their own length (Parazo, et al., 1991). To reduce cannibalism graders are used to separate the biggers ones from the small ones (Kungvankij, et al., 1986, Parazo, et al., 1990). Frequent handling from grading and from cannibalism itself can cause stress and physical damage causing disease problems. One approach to minimize cannibalism coupled with minimum handling is through the development of a sound feeding strategy whereby fingerlings are grown faster and of almost similar sizes. These can be achieved by providing the fingerlings with sufficient amount of feed and feeding them frequently.

This study is aimed to provide initial information on the use of a feeding program for the Asian sea bass to maximize its growth and obtain the highest production at higher salinities. 


\section{Materials and Methods}

The experiment was conducted at the Fish Farming Center of the Ministry of Agriculture in Abhur along the Red Sea coast over a 60-days period. Three feeding rates namely; $5 \%, 10 \%$ and $20 \%$ of the total body weight of fish and 3 feeding frequencies of $1 \mathrm{X}, 2 \mathrm{X}$ and $4 \mathrm{X}$ per day were used in this study. The study was carried out in a $3 \times 3$ factorial randomized complete block design (RCBD) as described by Gomez and Gomez (1984). Nine treatment combinations of the two factors (3 feeding rates multiplied by 3 feeding frequencies) with each treatment replicated three times for a total of 27 experimental units. The feed used is locally produced by ARASCO* and contains $48 \%$ protein. The feed size ranged from 1.00 to $2.00 \mathrm{~mm}$ in crumble form.

Asian sea bass fingerlings with a mean weight of $5 \mathrm{~g}$ were stocked in 27 plastic units of 60 liters capacity installed in at the Fish Farming Center, each unit filled with 50 liters sea water volume, stocked with 25 fingerlings and provided with aeration. Fingerlings growth in terms of weight and length were measured weekly with $20 \%$ of the population sampled. From this data mean weights and mean lengths were computed. From the weight data, the following parameters were computed; Average Daily Growth Rate (ADGR), which is growth of fish in g per day, is computed based on the following formula: ADGR, $g /$ day $=\mathrm{W}_{2}-\mathrm{W}_{1} / \mathrm{d}$, Where: $\mathrm{W}_{2}=$ the mean weight of the fish in the following sampling, $\mathrm{W}_{1}$ $=$ the mean weight of the fish in the first or previous sampling. Specific Growth Rate (SGR), which is the growth of fish in percent per day, is computed based on the following formula: $\mathrm{SGR}=\ln \mathrm{W}_{2}-\ln \mathrm{W}_{1} / \mathrm{d}$ $\times 100$, Where: $\ell_{\mathrm{n}} \mathrm{W}_{2}=$ the natural logarithm of the mean weight of the fish in the following sampling, $\ell_{\mathrm{n}} \mathrm{W}_{1}=$ the natural logarithm of the mean weight of the fish in the first or previous sampling and $d=$ the number of days between sampling. The number of fish per unit were counted weekly to determine the survival and for feed adjustment. Survival Rate (SR) in percent is computed based on the following formula: SR, $\%=\mathrm{N}_{2}$ $\div \mathrm{N}_{1} \times 100$, Where: $\mathrm{N}_{2}=$ the remaining number of fish per experimental unit and $\mathrm{N}_{1}=$ the initial number of fish per experimental unit.

From the resulting data on the mean weight and survival rate the biomass (B) in each facility was computed by multiplying the mean weight by the number of the remaining fish in each cage. The difference

\footnotetext{
*ARASCO is a feed manufacturing company located in Riyadh, Kingdom of Saudi Arabia.
} 
in biomass between sampling is production or biomass increase (BI). Hence the formula, the get feed conversion (FCR) is computed by the following formula: $\mathrm{FCR}=\mathrm{TFC} / \mathrm{BI}$, Where: $\mathrm{TFC}=$ the total amount of feed $(\mathrm{kg})$ used per experimental unit and $\mathrm{BI}=$ the difference in biomass $(\mathrm{kg})$ between sampling per experimental unit (B2-B1). Protein efficiency ratio (PER) were computed from the resulting data on growth using the formula: PER $=\mathrm{BI} / \mathrm{TPC}$, Where: $\mathrm{BI}=$ the difference in biomass $(\mathrm{kg})$ between sampling per experimental unit and TPC $=$ the total amount of protein consumed per experimental unit. If a feed contains $40 \%$ protein each $\mathrm{kg}$ has $0.40 \mathrm{~kg}$ protein. All analyses were based on the experimental design which is randomized complete block design, RCBD (Gomez and Gomez, 1984). Water quality parameters such as temperature, $\mathrm{pH}$, salinity and oxygen, were monitored daily using portable instruments, while critical parameters such as unionized ammonia $\left(\mathrm{NH}_{3}\right)$ and nitrite $\left(\mathrm{NO}_{2}\right)$ were measured weekly using titration methods as specified by APHA (1980).

All the data gathered were analyzed statistically using analyses of variance (ANOVA) to test the significant differences between treatments and the Duncan's Multiple Range Test (DMRT) was used to compare treatment means. Regression analyses were used to determine the relationships existing between the independent variables (feeding rate and frequency) and the dependent variables (weight, survival, FCR and water quality parameters). Coefficient of determination $\left(\mathrm{R}^{2}\right)$ and t-test were used to determine the significance of relationship.

\section{Results}

\section{Growth}

Asian sea bass fingerling growth in terms of body weight as related to feeding rate in feeding rates (FR) showed that fingerlings fed the highest level (4\%) exhibited the highest growth of $11.38 \mathrm{~g}$ at the end of the experiment followed by $2 \%$ with $8.76 \mathrm{~g}$ and $1 \%$ with $6.26 \mathrm{~g}$ after 60 days of rearing (Table 1). Correspondingly, the highest daily body growth of $0.1334 \mathrm{~g}$ was achieved in $4 \%$ feeding rate, followed by 0.0866 $\mathrm{g}$ at $2 \%$ and $0.0418 \mathrm{~g}$ at $1 \%$ (Table 2). SGR showed the highest value of $1.51 \%$ in $4 \%$ feeding rate, $1.41 \%$ in $2 \%$ and $1.25 \%$ in $1 \%$ (Table 2 ). Moreover, body length was highest in group fed 4\% with a mean of 9.84 $\mathrm{mm}$, followed by $2 \%$ with $8.96 \mathrm{~mm}$ and $8.05 \mathrm{~mm}$ in $1 \%$ (Table 2). There 
were significant differences in all the feeding levels from the first sampling after 15 days until final sampling after 60 days $(\mathrm{P}<0.0001)$, Also, significant differences were found in mean body weights, daily body growth, SGR and body length among feeding rates $(\mathrm{P}<0.0001)$.

Table 1. Bi-weekly mean growth in body weight (g) of Asian fingerlings at feeding rates $1 \%$, $2 \%, 4 \%$ given at feeding frequencies of $1 \mathrm{X}, 2 \mathrm{X}$ and $4 \mathrm{X}$ daily (Initial Weight $=3.5 \mathrm{~g}$ ).

After 15 days

\begin{tabular}{|c|c|c|c|c|}
\hline \multirow{2}{*}{ Feeding Rate (FR) } & \multicolumn{3}{|c|}{ Feeding Frequencies (FF) } & \multirow{2}{*}{ Mean $^{*}$} \\
\cline { 2 - 5 } & $\mathbf{1 x}$ & $\mathbf{2 x}$ & $\mathbf{4 x}$ & \\
\hline $1 \%$ & 4.71 & 4.89 & 4.70 & $4.77^{\mathrm{c}}$ \\
$2 \%$ & 5.18 & 5.20 & 5.23 & $5.20^{\mathrm{b}}$ \\
$4 \%$ & 5.59 & 5.79 & 5.76 & $5.71^{\mathrm{a}}$ \\
\hline Mean $^{*}$ & 5.16 & 5.29 & 5.23 & 5.23 \\
\hline
\end{tabular}

After 30 days

\begin{tabular}{|c|c|c|c|c|}
\hline $1 \%$ & 5.22 & 5.53 & 5.15 & $6.78^{\mathrm{c}}$ \\
$2 \%$ & 5.63 & 5.86 & 5.84 & $5.78^{\mathrm{b}}$ \\
$4 \%$ & 6.02 & 6.91 & 7.41 & $6.78^{\mathrm{a}}$ \\
\hline Mean $^{*}$ & $5.62^{\mathrm{b}}$ & $6.10^{\mathrm{a}}$ & $6.13^{\mathrm{a}}$ & 5.95 \\
\hline
\end{tabular}

After 45 days

\begin{tabular}{|c|c|c|c|c|}
\hline $1 \%$ & 5.68 & 5.95 & 5.77 & $5.80^{\mathrm{c}}$ \\
$2 \%$ & 6.53 & 6.93 & 7.53 & $7.00^{\mathrm{b}}$ \\
$4 \%$ & 7.37 & 8.47 & 9.00 & $8.28^{\mathrm{a}}$ \\
\hline Mean $^{*}$ & $6.53^{\mathrm{b}}$ & $7.12^{\mathrm{a}}$ & $7.44^{\mathrm{a}}$ & 7.03 \\
\hline
\end{tabular}

After 60 days

\begin{tabular}{|c|c|c|c|c|}
\hline $1 \%$ & 6.19 & 6.40 & 6.18 & $6.26^{\mathrm{c}}$ \\
$2 \%$ & 8.15 & 8.48 & 9.63 & $8.76^{\mathrm{b}}$ \\
$4 \%$ & 9.64 & 11.80 & 12.71 & $11.38^{\mathrm{a}}$ \\
\hline Mean $^{*}$ & $7.99^{\mathrm{c}}$ & $8.89^{\mathrm{b}}$ & $9.51^{\mathrm{a}}$ & 8.80 \\
\hline
\end{tabular}

${ }^{*}$ Means with different superscripts are significantly different using Duncan's Multiple Range Test (DMRT).

Table 2. Actual daily growth rate (g), specific growth rate (\%) and final length $(\mathrm{mm})$ in Asian fingerlings at feeding rates $1 \%, 2 \%, 4 \%$ given at feeding frequencies of $1 X, 2 X$ and $4 X$ daily after 60 days rearing period.

Actual Daily Growth Rate (g/day)

\begin{tabular}{|c|c|c|c|c|}
\hline \multirow{2}{*}{ Feeding Rate (FR) } & \multicolumn{3}{|c|}{ Feeding Frequencies } & \multirow{2}{*}{ Mean } \\
\cline { 2 - 4 } & $\mathbf{1 x}$ & $\mathbf{2 x}$ & $\mathbf{4 x}$ & \\
\hline $1 \%$ & 0.0407 & 0.0443 & 0.0403 & $0.0418^{\mathrm{c}}$ \\
$2 \%$ & 0.0760 & 0.0817 & 0.1020 & $0.0866^{\mathrm{b}}$ \\
$4 \%$ & 0.1023 & 0.1407 & 0.1573 & $0.1334^{\mathrm{a}}$ \\
\hline Mean $^{*}$ & $0.0730^{\mathrm{c}}$ & $0.0889^{\mathrm{b}}$ & $0.0999^{\mathrm{a}}$ & 0.0873 \\
\hline
\end{tabular}


Table 2. Contd.

SGR (\%)

\begin{tabular}{|c|c|c|c|c|}
\hline \multirow{2}{*}{ Feeding Rate (FR) } & \multicolumn{3}{|c|}{ Feeding Frequencies } & \multirow{2}{*}{ Mean $^{*}$} \\
\cline { 2 - 5 } & $\mathbf{1 x}$ & $\mathbf{2 x}$ & $\mathbf{4 x}$ & \\
\hline $1 \%$ & 0.82 & 0.86 & 0.82 & $0.83^{\mathrm{c}}$ \\
$2 \%$ & 1.31 & 1.39 & 1.61 & $1.44^{\mathrm{b}}$ \\
$4 \%$ & 1.61 & 1.97 & 2.11 & $1.90^{\mathrm{a}}$ \\
\hline Mean $^{*}$ & $1.25^{\mathrm{c}}$ & $1.41^{\mathrm{b}}$ & $1.51^{\mathrm{a}}$ & 1.39 \\
\hline
\end{tabular}

Final Length at 60 days $(\mathrm{mm})$

\begin{tabular}{|c|c|c|c|c|}
\hline $1 \%$ & 8.07 & 8.05 & 8.03 & $8.05^{\mathrm{c}}$ \\
$2 \%$ & 8.55 & 9.01 & 9.30 & $8.96^{\mathrm{b}}$ \\
$4 \%$ & 9.30 & 9.89 & 10.33 & $9.84^{\mathrm{a}}$ \\
\hline Mean $^{*}$ & $8.64^{\mathrm{b}}$ & $8.99^{\mathrm{a}}$ & $9.22^{\mathrm{a}}$ & 8.95 \\
\hline
\end{tabular}

Initial Length $-6.5 \mathrm{~mm}$

*Means with different superscripts are significantly different using Duncan's Multiple Range Test (DMRT).

Growth in feeding frequency treatments showed that fingerlings fed four times (4X) exhibited the fastest and best growth of $9.51 \mathrm{~g}$ followed by $2 \mathrm{X}$ with $8.89 \mathrm{~g}$ and $1 \mathrm{X}$ with $7.99 \mathrm{~g}$ after 60 days of rearing (Table 1 ). Correspondingly, the highest daily growth of $0.0999 \mathrm{~g}$ was achieved in $4 \mathrm{X}$ feeding frequency, followed by $0.0889 \mathrm{~g}$ at $2 \mathrm{X}$ and $0.0730 \mathrm{~g}$ at $1 \mathrm{X}$ (Table 2). Likewise, SGR showed the highest value of $1.51 \%$ in $4 \mathrm{X}$ feeding times, $1.41 \%$ in $2 \mathrm{X}$ and $1.25 \%$ in $1 \mathrm{X}$ (Table 2). Higher growth in body length was obtained in feeding frequency of $4 \mathrm{X}$ with $9.22 \mathrm{~mm}$ followed by $2 \mathrm{X}$ with $8.99 \mathrm{~mm}$ and $1 \mathrm{X}$ with 8.64 (Table 2). Significantly differences were found in body weight means in all the feeding frequencies from the first sampling after 15 days until final sampling of after 60 days. However weights between $2 X$ and $4 X$ feeding times were not significantly different from the 15 days to the 45 days (Table 1). Body weights, daily body weight and SGR growth showed significant differences among feeding frequencies $(\mathrm{P}<0.0001)$. The final body length of $2 \mathrm{X}$ and $4 \mathrm{X}$ were not significantly different but these two differed significantly with $1 \mathrm{X}(\mathrm{P}<0.001)$.

Analysis of variance for a two experiment factors showed significant interaction results on growth, final weight $(\mathrm{P}<0.002)$, ADGR $(\mathrm{P}<0.002)$, SGR $(\mathrm{P}<0.003)$ and final body length $(\mathrm{P}<0.05)$. 


\section{Feed Conversion Ratio and Protein Efficiency Ratio}

FCR in the three feeding rates was $1.08,1.19$ and 1.74 for $1 \%, 2 \%$ and $4 \%$ respectively (Table 3 , Fig. 1). Significant differences $(\mathrm{P}<0.0001)$ between $1 \%$ and the other two rates but on the other hand $2 \%$ and $4 \%$ did not differ significantly (Table 3 ). Lesser feed rates of $1 \%$ and $2 \%$ showed better feed conversion as this amount is totally consumed by the Asian fingerlings when compared with $4 \%$. On the other hand, PER found to be significantly better in $1 \%$ with $1.95 \%$, followed by $2 \%$ with $1.78 \%$ and $4 \%$ with $1.21 \%$. Significant differences in PER at all the three feeding levels from one another $(\mathrm{P}<0.0001)$ (Table 3$)$.

Feed conversions in feeding frequencies treatments were 1.49, 1.29 and 1.23 for $1 \mathrm{X}, 2 \mathrm{X}$ and $4 \mathrm{X}$ respectively (Table 3, Fig. 1). Significant difference $(\mathrm{P}<0.001)$ between $4 \mathrm{X}$ and $1 \%$ \& $2 \%$ rates, but on the other hand $1 \%$ and $2 \%$ did not differ significantly (Table 3 ). Protein assimilation found to be significantly better in $4 \mathrm{X}$ with $1.76 \%$, followed by $2 \mathrm{X}$ with $1.68 \%$ and $1 \mathrm{X}$ with $1.51 \%(\mathrm{P}<0.05)$. PER in $4 \mathrm{X}$ and $2 \mathrm{X}$ did not significantly differ but $4 \mathrm{X}$ differed significantly with $1 \mathrm{X}$ which in turn differs with $2 \mathrm{X}$ (Table 3 ). Analysis of variance for a two factor experiment showed significant interaction results on feed conversion but not on protein utilization $(\mathrm{P}<0.01)$.

Table 3. Feed conversion ratio(FCR), protein efficiency ratio, PER (\%) in Asian fingerlings (g) at feeding rates $1 \%, 2 \%, 4 \%$ given at feeding frequencies of $1 \mathrm{X}, 2 \mathrm{X}$ and $4 \mathrm{X}$ daily after 60 days rearing period.

Feed Conversion Ratio

\begin{tabular}{|c|c|c|c|c|}
\hline \multirow{2}{*}{$\%$ Feeding Rate } & \multicolumn{3}{|c|}{ Feeding Frequencies } & \multirow{2}{*}{ Mean $^{*}$} \\
\cline { 2 - 4 } & $\mathbf{1 x}$ & $\mathbf{2 x}$ & $\mathbf{4 x}$ & \\
\hline $1 \%$ & 1.12 & 1.02 & 1.08 & $1.08^{\mathrm{b}}$ \\
$2 \%$ & 1.27 & 1.22 & 1.07 & $1.19^{\mathrm{b}}$ \\
$4 \%$ & 2.07 & 1.63 & 1.53 & $1.74^{\mathrm{a}}$ \\
\hline Mean $^{*}$ & $1.49^{\mathrm{a}}$ & $129^{\mathrm{b}}$ & $1.23^{\mathrm{b}}$ & 1.34 \\
\hline
\end{tabular}

Protein Efficiency Ratio (\%)

\begin{tabular}{|c|c|c|c|c|}
\hline $1 \%$ & 1.87 & 2.04 & 1.95 & $1.95^{\mathrm{a}}$ \\
$2 \%$ & 1.66 & 1.72 & 1.96 & $1.78^{\mathrm{b}}$ \\
$4 \%$ & 1.01 & 1.27 & 1.37 & $1.21^{\mathrm{c}}$ \\
\hline Mean $^{*}$ & $1.51^{\mathrm{b}}$ & $1.68^{\mathrm{ab}}$ & $1.76^{\mathrm{a}}$ & 1.65 \\
\hline
\end{tabular}

*Means with different superscripts are significantly different using Duncan's Multiple Range Test (DMRT). 


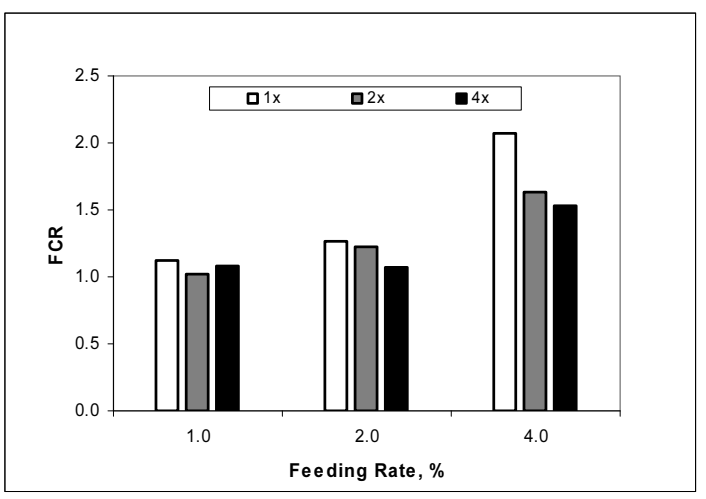

Fig. 1. Interaction effect on feed conversion (FCR) in Asian sea bass fingerlings fed at three feeding rates $(1 \%, 2 \%$ and $4 \%)$ and feeding frequencies $(1 \mathrm{X}, 2 \mathrm{X}$ and $4 \mathrm{X})$ under hypersaline condition.

\section{Survival Rate}

Fingerling survival in all the feeding rates were almost $100 \%$ with $1 \%$ having $98.7 \%, 2 \%$ yielding $99.6 \%$ and $4 \%$ with $98.7 \%$ (Table 4 ). Statistics showed significant differences in survival rates with $2 \%$ differing from $1 \%$ and $4 \%(\mathrm{P}<0.05)$ (Table 4$)$. Fingerling survival in all the feeding frequencies were almost $100 \%$ (Table 4) with $1 \mathrm{X}$ and $2 \mathrm{X}$ having $99.1 \%$, and $4 \mathrm{X}$ with $99.7 \%$. Significant differences in survival rates with $1 \mathrm{X}$ and $2 \mathrm{X}$ differing from $4 \mathrm{X}(\mathrm{P}<0.05)$ (Table 4). Simple regression analyses showed no relationship between feeding rates and feeding frequencies and survival rate as supported by the low insignificant coefficient of determination $\left(\left(\mathrm{R}^{2}=0.08\right.\right.$ and 0.001$)$ respectively. Analysis of variance for a two factor experiment showed significant interaction results on survival rates $(\mathrm{P}<0.003)$.

Table 4. Survival rate (\%) in Asian fingerlings, after 60 days rearing in hypersaline Red Sea water at feeding rates $1 \%, 2 \%, 4 \%$ given daily at feeding frequencies of $1 \mathrm{X}, 2 \mathrm{X}$ and $4 X$.

Survival Rate (\%)

\begin{tabular}{|c|c|c|c|c|}
\hline \multirow{2}{*}{ \% Feeding Rate } & \multicolumn{3}{|c|}{ Feeding Frequencies } & \multirow{2}{*}{ Mean* $^{*}$} \\
\cline { 2 - 4 } & $\mathbf{1 x}$ & $\mathbf{2 x}$ & $\mathbf{4 x}$ & \\
\hline $1 \%$ & 98.7 & 98.7 & 98.7 & $98.7^{\mathrm{b}}$ \\
$2 \%$ & 100.0 & 100.0 & 98.7 & $99.6^{\mathrm{a}}$ \\
$4 \%$ & 98.7 & 98.7 & 98.7 & $98.7^{\mathrm{b}}$ \\
\hline Mean $^{*}$ & $99.1^{\mathrm{b}}$ & $99.1^{\mathrm{b}}$ & $98.7^{\mathrm{a}}$ & 99.0 \\
\hline
\end{tabular}

${ }^{*}$ Means with different superscripts are significantly different using Duncan's Multiple Range Test (DMRT). 


\section{Water Quality}

Table 5 shows the ranges in water quality measured for all feeding rate, feeding frequency treatments. In all the treatments temperature ranged from 28 to $31^{\circ} \mathrm{C}$, $\mathrm{pH}$ ranged from 7.2 to 7.6 in $1 \%$ feeding rate, 7.0 to 7.6 in $2 \%$ and 6.5 to 7.5 in $4 \%$, total ammonia (TAN) varied from 0.01 to $0.08 \mathrm{ppm}$ in $1 \%$ feeding rate, 0.01 to $0.18 \mathrm{ppm}$ in $2 \%$ and 0.01 to $0.8 \mathrm{ppm}$ in $4 \%$. Nitrite $\left(\mathrm{NO}_{2}\right)$ ranged from 0.01 to $0.03 \mathrm{ppm}$ in $1 \%, 0.01$ to $0.02 \mathrm{ppm}$ in $2 \%$ and in $4 \%$ it was 0.01 to $0.02 \mathrm{ppm}$ Dissolved oxygen (DO) ranged from 4.8 to $6.5 \mathrm{ppm}$ in $1 \%, 4.6$ to 5.8 in $2 \%$ and 4.5 to 6.1 in $4 \%$.

Simple regression analyses showed no significant relationship existed between feeding frequencies and critical water quality parameters such as total ammonia $\left(\mathrm{R}^{2}=0.10\right)$, nitrite $\left(\mathrm{R}^{2}=0.08\right), \mathrm{pH}\left(\mathrm{R}^{2}=0.01\right)$ and oxygen $\left(\mathrm{R}^{2}=0.34\right)$ as supported by the low insignificant coefficient of determination $\left(\mathrm{R}^{2}\right)$ values.

Critical water quality parameters (Table 6) such as total ammonia (TAN); nitrite $\left(\mathrm{NO}_{2}\right)$ and dissolved oxygen (DO) were found to be significantly different among the three feeding rates $(\mathrm{P}<0.0001)$. Total ammonia in $4 \%$ feeding rate was highest at $0.210 \mathrm{ppm}$, followed by $2 \%$ with $0.047 \mathrm{ppm}$ and $1 \%$ with $0.030 \mathrm{ppm}$. Nitrite level was also highest in $4 \%$ with $0.023 \mathrm{ppm}$ followed by $2 \%$ with $0.017 \mathrm{ppm}$ and $1 \%$ with 0.015 ppm. Dissolved oxygen on the other hand was highest in 1\% with 5.73 ppm followed by $2 \%$ with $5.57 \mathrm{ppm}$ and $4 \%$ with $5.40 \mathrm{ppm}$. Simple regression analyses showed significant relationship existed between feeding rates and critical water quality parameters such as total ammonia $\left(\mathrm{R}^{2}=0.59\right)$, nitrite $\left(\mathrm{R}^{2}=0.57\right)$ and $\mathrm{pH}\left(\mathrm{R}^{2}=0.91\right)$ except for oxygen $\left(\mathrm{R}^{2}\right.$ $=0.27)$ as supported by the significant coefficient of determination $\left(\mathrm{R}^{2}\right)$. Higher levels of total ammonia and nitrite were observed with increasing feeding rate because the feed used in the experiment contain $48 \%$ protein.

Among feeding frequencies critical water quality parameters such as total ammonia (TAN), nitrite $\left(\mathrm{NO}_{2}\right)$ and dissolved oxygen (DO) were found to be significantly different $(\mathrm{P}<0.0001)$ (Table 6). Total ammonia in $4 \mathrm{X}$ feeding was highest at $0.143 \mathrm{ppm}$, followed by $2 \mathrm{X}$ with $0.073 \mathrm{ppm}$ and $1 \mathrm{X}$ with $0.070 \mathrm{ppm}$. Nitrite level was also highest in $4 \mathrm{X}$ with 0.017 


\begin{tabular}{|c|c|c|c|c|c|c|c|c|c|c|}
\hline \multirow{2}{*}{ 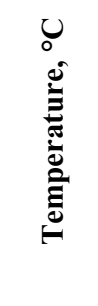 } & 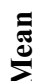 & $\begin{array}{l}\tilde{N} \\
\ddot{n}\end{array}$ & ஜ̊̀े & $\ddot{\text { ते }}$ & $\begin{array}{l}\tilde{\lambda} \\
\dddot{N}\end{array}$ & $\ddot{n}$ & $\begin{array}{l}n \\
\stackrel{n}{1}\end{array}$ & $\tilde{\curvearrowright}$ & $\tilde{\curvearrowright}$ & $\tilde{\text { กิ }}$ \\
\hline & 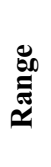 & $\begin{array}{l}0 \\
\dot{m} \\
1 \\
0 \\
0 \\
\infty \\
i\end{array}$ & $\begin{array}{l}\stackrel{0}{\dot{m}} \\
\dot{m} \\
1 \\
0 \\
\infty \\
\dot{i}\end{array}$ & $\begin{array}{l}0 \\
\stackrel{0}{\dot{m}} \\
0 \\
1 \\
0 \\
\dot{0} \\
i\end{array}$ & $\begin{array}{l}0 \\
\dot{m} \\
1 \\
0 \\
0 \\
\infty \\
i\end{array}$ & $\begin{array}{l}0 \\
\dot{m} \\
1 \\
0 \\
0 \\
\infty \\
\dot{N}\end{array}$ & $\begin{array}{l}0 \\
\dot{m} \\
1 \\
1 \\
0 \\
\infty \\
\infty\end{array}$ & $\begin{array}{l}0 \\
\dot{m} \\
1 \\
0 \\
\infty \\
\infty \\
i\end{array}$ & $\begin{array}{l}0 \\
\dot{m} \\
1 \\
0 \\
0 \\
\infty \\
\sim\end{array}$ & $\begin{array}{l}0 \\
\dot{m} \\
1 \\
0 \\
\infty \\
\infty \\
i\end{array}$ \\
\hline \multirow{2}{*}{ 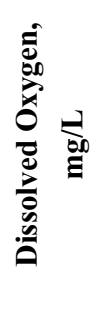 } & $\stackrel{\Xi}{\tilde{E}}$ & $\stackrel{0}{0}$ & $\begin{array}{l}\infty \\
\text { in }\end{array}$ & $\begin{array}{l}\stackrel{+}{n} \\
\dot{n}\end{array}$ & के & $\stackrel{\nabla}{\sim}$ & $\stackrel{\nabla}{i}$ & $\begin{array}{l}\sigma \\
\dot{n}\end{array}$ & $\dot{v}$ & ஸִ \\
\hline & 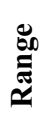 & $\begin{array}{l}n \\
0 \\
1 \\
n \\
n\end{array}$ & $\begin{array}{l}\text { フै } \\
1 \\
+ \\
\dot{\sim}\end{array}$ & $\begin{array}{l}n \\
n \\
1 \\
\sim 1 \\
n\end{array}$ & $\begin{array}{l}n \\
n \\
1 \\
n \\
n\end{array}$ & $\begin{array}{l}\infty \\
\dot{n} \\
1 \\
0 \\
\dot{r}\end{array}$ & $\begin{array}{l}\infty \\
\dot{1} \\
1 \\
9 \\
\dot{+}\end{array}$ & $\begin{array}{l}n \\
0 \\
1 \\
\infty \\
\dot{+}\end{array}$ & $\begin{array}{l}-\overrightarrow{0} \\
1 \\
0 \\
\dot{+}\end{array}$ & $\begin{array}{l}9 \\
i \\
1 \\
n \\
\dot{r}\end{array}$ \\
\hline \multirow{2}{*}{ 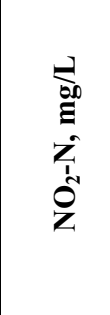 } & $\stackrel{\Xi}{\Sigma}$ & $\stackrel{n}{0}$ & $\frac{n}{0}$ & $\begin{array}{l}\frac{n}{0} \\
0 \\
0\end{array}$ & $\stackrel{n}{0}$ & 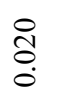 & $\begin{array}{l}n \\
0 \\
0\end{array}$ & ஜ̂ & $\begin{array}{l}\text { రి } \\
\stackrel{0}{0}\end{array}$ & 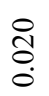 \\
\hline & 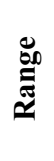 & $\begin{array}{l}\tilde{O} \\
0 \\
0 \\
1 \\
0 \\
0 \\
0\end{array}$ & 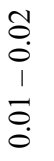 & $\begin{array}{l}\tilde{o} \\
0 \\
1 \\
1 \\
0 \\
0 \\
0\end{array}$ & $\begin{array}{l}\tilde{o} \\
0 \\
0 \\
1 \\
0 \\
0 \\
0\end{array}$ & $\begin{array}{l}\tilde{o} \\
0 \\
0 \\
1 \\
0 \\
0 \\
0\end{array}$ & $\begin{array}{l}\tilde{o} \\
0 \\
0 \\
1 \\
0 \\
0 \\
0\end{array}$ & $\begin{array}{l}0 \\
0 \\
0 \\
1 \\
0 \\
0 \\
0\end{array}$ & $\begin{array}{l}\tilde{o} \\
0 \\
1 \\
1 \\
0 \\
0\end{array}$ & 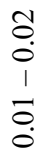 \\
\hline \multirow{2}{*}{ 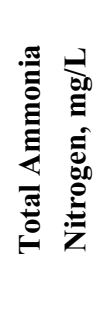 } & $\stackrel{\bar{E}}{\stackrel{\Xi}{\Sigma}}$ & $\begin{array}{l}\widetilde{o} \\
\stackrel{0}{0}\end{array}$ & $\stackrel{t}{\stackrel{0}{0}}$ & $\stackrel{m}{0}$ & $\stackrel{+}{0}$ & $\stackrel{8}{\circ}$ & $\stackrel{\Xi}{0}$ & $\frac{n}{0}$ & $\stackrel{I}{\circ}$ & $\begin{array}{l}0 \\
? \\
0\end{array}$ \\
\hline & 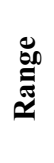 & $\begin{array}{l}0 \\
0 \\
0 \\
1 \\
0 \\
0 \\
0\end{array}$ & $\begin{array}{l}\hat{0} \\
\dot{0} \\
1 \\
0 \\
\dot{0}\end{array}$ & 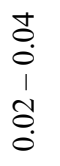 & $\begin{array}{l}0 \\
0 \\
0 \\
1 \\
0 \\
0 \\
0\end{array}$ & $\begin{array}{l}0 \\
0 \\
0 \\
1 \\
1 \\
0 \\
0\end{array}$ & $\begin{array}{l}\hat{0} \\
\ddot{0} \\
1 \\
0 \\
0 \\
0\end{array}$ & $\begin{array}{l}\infty \\
0 \\
0 \\
1 \\
0 \\
0 \\
0\end{array}$ & $\begin{array}{l}\infty \\
0 \\
0 \\
1 \\
8 \\
0 \\
0\end{array}$ & \begin{tabular}{l}
0 \\
0 \\
0 \\
1 \\
1 \\
\hdashline \\
0
\end{tabular} \\
\hline \multicolumn{2}{|l|}{ 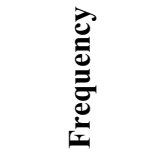 } & - & $\sim$ & $\nabla$ & - & $N$ & $\nabla$ & - & $\sim$ & $\nabla$ \\
\hline \multicolumn{2}{|c|}{ 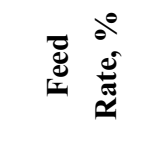 } & - & - & - & $\sim$ & $N$ & $N$ & $\nabla$ & $\nabla$ & + \\
\hline
\end{tabular}


ppm followed by $2 \mathrm{X}$ with $0.018 \mathrm{ppm}$ and $1 \mathrm{X}$ with $0.020 \mathrm{ppm}$. Dissolved oxygen on the other hand was highest in $1 \mathrm{X}$ with $5.83 \mathrm{ppm}$ followed by $2 \mathrm{X}$ with $5.53 \mathrm{ppm}$ and $4 \%$ with $5.33 \mathrm{ppm}$. Analysis of variance for a two factor experiment showed significant interaction results on total ammonia, nitrite and dissolved oxygen $(\mathrm{P}<0.0001)$.

Table 6. Total ammonia nitrogen, TAN (ppm), nitrite, $\mathrm{NO}_{2}-\mathrm{N}$ (ppm) dissolved oxygen, DO (ppm) during the rearing of Asian fingerlings at feeding rates $1 \%, 2 \%, 4 \%$ given at feeding frequencies of $1 \mathrm{X}, 2 \mathrm{X}$ and $4 \mathrm{X}$ daily using hypersaline Red Sea water.

Total Ammonia Nitrogen (TAN)

\begin{tabular}{|c|c|c|c|c|}
\hline \multirow{2}{*}{$\%$ Feeding Rate } & \multicolumn{3}{|c|}{ Feeding Frequencies } & \multirow{2}{*}{ Mean* } \\
\hline & $\mathbf{1 x}$ & $2 x$ & $4 x$ & \\
\hline $\begin{array}{l}1 \% \\
2 \% \\
4 \%\end{array}$ & $\begin{array}{l}0.020 \\
0.040 \\
0.150\end{array}$ & $\begin{array}{l}0.040 \\
0.060 \\
0.120\end{array}$ & $\begin{array}{l}0.030 \\
0.040 \\
0.360\end{array}$ & $\begin{array}{l}0.030^{\mathrm{c}} \\
0.047^{\mathrm{b}} \\
0.210^{\mathrm{a}}\end{array}$ \\
\hline Mean $^{*}$ & $0.070^{\mathrm{c}}$ & $0.073^{\mathrm{b}}$ & $0.143^{\mathrm{a}}$ & 0.096 \\
\hline \multicolumn{5}{|l|}{$\mathrm{NO}_{2}-\mathrm{N}$} \\
\hline $\begin{array}{l}1 \% \\
2 \% \\
4 \% \\
\end{array}$ & $\begin{array}{l}0.015 \\
0.015 \\
0.030 \\
\end{array}$ & $\begin{array}{l}0.015 \\
0.020 \\
0.020 \\
\end{array}$ & $\begin{array}{l}0.015 \\
0.015 \\
0.020 \\
\end{array}$ & $\begin{array}{l}0.015^{\mathrm{c}} \\
0.017^{\mathrm{b}} \\
0.023^{\mathrm{a}}\end{array}$ \\
\hline Mean $^{*}$ & $0.020^{\mathrm{a}}$ & $0.018^{\mathrm{b}}$ & $0.017^{\mathrm{c}}$ & 0.018 \\
\hline \multicolumn{5}{|c|}{ Dissolved Oxygen (DO) } \\
\hline $\begin{array}{l}1 \% \\
2 \% \\
4 \% \\
\end{array}$ & $\begin{array}{l}6.00 \\
5.90 \\
5.60 \\
\end{array}$ & $\begin{array}{l}5.80 \\
5.40 \\
5.40 \\
\end{array}$ & $\begin{array}{l}5.40 \\
5.40 \\
5.20 \\
\end{array}$ & $\begin{array}{l}5.733^{\mathrm{a}} \\
5.567^{\mathrm{b}} \\
5.400^{\mathrm{c}}\end{array}$ \\
\hline Mean* & $5.833^{\mathrm{a}}$ & $5.533^{b}$ & $5.333^{\mathrm{c}}$ & 5.567 \\
\hline
\end{tabular}

*Means with different superscripts are significantly different using Duncan's Multiple Range Test (DMRT).

\section{Discussion}

In all the growth parameters measured namely weight, ADGR SGR, and length, the highest feeding rate of $4 \%$ proved to be the best level for Asian sea bass fingerling rearing under hypersaline condition, having exhibited the highest values. The growth performance in the two feeding levels seems to indicate that these are for maintenance ration only for the fingerlings. Similar results were obtained by Harpaz, et al., (2005) using the same species (Lates calcarifer) but in freshwater, and using $20 \mathrm{~g}$ juveniles, found out that restricted feeding ( $2 \%$ feeding rate) reduced growth rate with the optimum feeding rate observed at $4 \%$ because $6 \%$ feeding rate did not improve growth. According to Pillay (1990) in Asian sea bass nursery rapidly growing fry of about $0.25 \mathrm{~g}$ generally require a 
feeding rate of as much as $10 \%$ of their weight daily, but as they grow and reach to about $4 \mathrm{~g}$ the ration can be reduced to 5\%. NRC (1977) mentioned that when insufficient amount of food is given to the fish, poor growth results since most of the food is used only for body maintenance. Optimal growth can only be attained if sufficient amount of feed is provided as in 4\% feeding rate in the experiment (Tacon, 1993, Alava, 2002). Simple regression analyses on growth showed significant coefficient of determination $\left(\mathrm{R}^{2}\right)$ in the three feeding rates, in relation to final weight $\left(\mathrm{R}^{2}=0.84\right)$, final length $\left(\mathrm{R}^{2}=0.82\right)$, ADGR $\left(\mathrm{R}^{2}=0.80\right)$ and SGR $\left(\mathrm{R}^{2}=0.84\right)$, indicating that growth can still be improved with increasing amount of food. Tyler and Dunn (1976) in their study on winter flounder (Pseudopleuronectes americanus), found that growth can increase linearly with increasing amount of food. Carlos, 1988 obtained similar trend in growth with increasing feeding rate in bighead carp Aristichythys nobilis fry. Chiu et al. and Das and Ray as cited by Seenappa and Devaraj (1991) also observed increases in the growth of Chanos chanos and Cirrhinus mrigala with increased feeding rates. Nour, et al., (1993) also found similar trend in Mugil cephalus fingerlings.

Feeding of Asian sea bass fingerlings at 4X/day (4times daily) improved growth rate expressed as final body weight ADGR, SGR, and final length. Chan, (1979) obtained similar results on common carp when he got faster growth using feeding frequencies of 3 and 5 times. Hashim et al., (1994) using catfish also found that the final average weight of groups fed 4 times daily was significantly higher than two times daily feeding. In Asian sea bass, Boonyaratpalin (1997) and Alava (2002) recommended a feeding frequency of $3 \mathrm{X}$ daily using juveniles of the same species but in normal seawater salinities indicating that this frequency is the optimum for the species. According to Pillay (1990) feeding frequency decreases from about $8 \mathrm{X}$ daily for fry weighing less than $1.5 \mathrm{~g}$ to 4 times a day for advanced fry.

Simple regression analyses on growth showed insignificant coefficient of determination $\left(\mathrm{R}^{2}\right)$ in the three feeding frequencies in relation to final weight $\left(\mathrm{R}^{2}=0.09\right)$, final length $\left(\mathrm{R}^{2}=0.0 .08\right)$, ADGR $\left(\mathrm{R}^{2}\right.$ $=0.0 .09)$ and SGR $\left(R^{2}=0.05\right)$. Windell (1976), in his frequency study on rainbow trout also did not find any influence on growth even when food 
was given one to eight times a day. Carlos, 1988 also did not find any relationship between feeding frequency and growth on bighead carp fry.

Analysis of variance for a two factor experiment showed significant interaction results on growth (final weight $\mathrm{P}<0.002$, ADGR $\mathrm{P}<0.002$, SGR $\mathrm{P}<0.003$ and final $\mathrm{P}<0.05$ ). Low feeding rate of $1 \%$ given more than $1 \mathrm{X}$ daily will result in poor growth, and higher feeding rates of 2 and $4 \%$ will result in better growth, if given between two to four times daily in Asian sea bass fingerlings under hypersaline condition. This is explained by the fact that less food given frequently, will result in feed loss, due to dissolution or leaching, hence poor growth results. This agrees well with Royce as cited by Carlos (1988), when he asserted that trout and salmon larval feeding requires correct size of food, frequent feeding, amount of food and possibly the combination of the three. Elliot as cited by Carlos (1988) further stressed that food consumption of trout Salmo trutta is affected by large number of features, such as the amount of food eaten, number of meals per day, and the combination of the three factors. Carlos (1988) also found significant interaction in bighead carp, Aristhcthys nobilis fry between feeding rate and feeding frequency considering final weight, ADGR and SGR.

From the results, frequent feeding of $4 \mathrm{X}$ yielded better feed conversion (FCR) and protein assimilation (PER) in Asian fingerlings at a salinity of 42 to $43 \mathrm{ppt}$. Chan (1979) also found out that frequent feeding of three to five, improved FCR in common carp. However in tilapia, feeding frequency affected FCR and PER which were favorable in fish maintained on a predetermined ration fed once or twice daily, compared to those fed thrice or four times daily (Silva et al., 1986). Chua and Teng, (1978) conducted a three month study on the effect of feeding frequency on the growth of young grouper. Optimal growth, good feed conversion, and high survival rate, were observed in satiation feeding with one feeding every two days. Tucker, et al. as cited by Boonyaratpalin (1997) using the Asian sea bass of 74 to $150 \mathrm{~g}$ size found out that feed conversion was significantly lower or better with one meal per day.

Simple regression analyses on feed utilization showed insignificant coefficient of determination $\left(\mathrm{R}^{2}\right)$ indicating that no relationship existed between the three feeding frequencies and FCR $\left(\mathrm{R}^{2}=0.09\right)$ and PER $\left(\mathrm{R}^{2}\right.$ $=0.08$ ). This can be explained by the fact that no significant difference in 
FCR and PER values was observed between $2 \mathrm{X}$ and $4 \mathrm{X}$ feeding. Analysis of variance for a two factor experiment showed significant interaction results on feed conversion but not on protein utilization $(\mathrm{P}<0.01)$. High feeding rate of $4 \%$ given $1 \mathrm{X}$ daily poor feed conversion resulted unlike in lower feeding rates of $1 \%$ and $2 \%$, due to the fact that not all the feeds were eaten as what was noted in the experiment, especially in the later part when fingerling mean weight increased. According to Alava (2002) optimal fish growth, and feed efficiency, can only be attained if sufficient amount of food is provided, completely ingested, and digested.

Based upon the results of the study, FCR and PER declined with increasing feeding rates as in the case of the Asian sea bass reared under hypersaline condition. This finding was similar to that of Seenappa and Devaraj (1991) who found out that food conversion and protein efficiency was better at lower rations in catla fry. Likewise, increasing feeding level in mullet fingerlings increased FCR (decrease in utilization efficiency) and PER (Nour, et al., 1993).

Simple regression analyses on feed utilization showed significant coefficient of determination $\left(\mathrm{R}^{2}\right)$ in the three feeding rates in relation to FCR $\left(\mathrm{R}^{2}=0.78\right)$ and PER $\left(\mathrm{R}^{2}=0.86\right)$. In the study, poor FCR and low PER resulted with increasing feeding rate. Nour, et al., 1993 observed similar pattern in mullet fingerling, when FCR increase (decrease in utilization efficiency) and protein efficiency ratio (PER) decreased. In catla fry feeding Seenappa and Devaraj (1991) also noted that feed efficiency decreased with increased feeding levels.

The water quality parameters were within the limits cited by Rimmer and Russel (1998) for the optimum rearing of Asian sea bass nursery and grow-out. This is the reason why all the stocks in the treatments yielded almost $100 \%$ survival rate.

\section{Conclusion}

Results of this study showed that the suitable feeding rate, and feeding frequency for rearing Asian sea bass fingerling of $(3.9 \mathrm{~g})$ in hypersaline condition of 42 to $43 \%$ salinity are $4 \%$, and $4 X$ respectively. It is recommended that higher feeding rates, and frequencies, must be tested on the same size of Asian sea bass fingerlings and grow out under hypersaline condition to determine if growth can still be improved. 


\section{Acknowledgment}

This research was carried out with support of Fish Farming Center (FFC), Ministry of Agriculture, Jeddah, Saudi Arabia. The author is thankful to Mr. Salim Althobaity for his assistance in providing experiment place, Asian sea bass fingerlings, and feeds to carry out these experiments. I am also grateful to every body that helped in this experiment in FFC.

\section{References}

Alava, V. (2002) Management of Feeding Aquaculture Species, in Nutrition in Tropical Aquaculture, Essentials of fish nutrition, feeds and feeding of tropical aquatic species. eds. O. Millamena, R. Coloso and F. Pascual, Aquaculture Department, Southeast Asian Fisheries Development Center, Tigbauan, Iloilo, Philippines, pp: 169-208.

Andrewa, J.E., Holm, J., Kadri, S. and Huntingford, F.A. (2004) The effect of competition on the feeding efficiency and feed handling behaviour in gilthead seabream (Sparus aurata L.) held in tanks, Aquaculture, 232: 317-331.

Andrews, J.W. and Page, J.W. (1975) The effects of frequency of feeding on the culture of catfish, Trans. Am. Fish. Soc., 104: 317-321.

APHA (1980) Standard Methods for the Examination of Water and Wastewater, $15^{\text {th }}$ Ed., Washington D.C., American Health Association, 1134 p.

Boonyaratpalin, M. (1997) Nutrient requirements of marine food fish cultured in Southeast Asia, Aquaculture, 151: 283-313.

Buurma, B.J. and Diana, J.S. (1994) Effects of feeding frequency and handling on growth and mortality of cultured walking catfish Clarias fuscus, J. World Aquac. Soc., 2: 175-182.

Carlos, M.H. (1988) Growth and survival of bighead carp (Aristicthys nobilis) fry fed at different intake levels and feeding frequencies, Aquaculture, 68: 267-276.

Chan, E. (1979) The response of carp (Cyprinus carpio, L.) to different feeding frequencies in floating net net cage cukture, Biotrop News L., 29: 15 p.

Chua, T.E. and Teng, S.K. (1978) Effects of feeding frequency on the growth of young estuary grouper, Epinephelus tauvina (Forskal) cultured in floating cages, Aquaculture, 14: 31-47.

Chua, T.E. and Teng, S.K. (1982) Effects of food ration on growth, condition factor, food conversion efficiency and net yield in floating net cages, Aquaculture, 27: 273-283.

FFC (2000) Fish Farming Center, Annual Report. Fish Farming Center, Ministry of Agriculture, Kingdom of Saudi Arabia, $40 \mathrm{p}$.

FFC (2001) Fish Farming Center, Annual Report. Fish Farming Center, Ministry of Agriculture, Kingdom of Saudi Arabia, 51 p.

FFC (2002) Fish Farming Center, Annual Report. Fish Farming Center, Ministry of Agriculture, Kingdom of Saudi Arabia, 43 p.

FFC (2003) Fish Farming Center, Annual Report. Fish Farming Center, Ministry of Agriculture, Kingdom of Saudi Arabia, $54 \mathrm{p}$.

Gomez, K.A. and Gomez, A.A. (1984) Statistical Procedures for Agricultural Research, John Wiley and Sons, Inc., New York U.S.A., 680 p.

Grayton, D.D. and Beamish, F.W.H. (1977) Effects of feeding frequency on food intake, growth and body composition of rainbow trout (Salmo gardnieri), Aquaculture, 11: 159-172. 
Harpaz, S., Hakim, Y., Barki, A., Karplus, I., Slosman, T. and Tufan Erolodogan, O. (2005) Effects of different feeding levels during day and/or night on growth and brush-border enzyme activity in juveniles Lates calcarifer reared in freshwater recirculating tanks, Aquaculture, 248: 325-335.

Hashim, R., Ali, A. and Ismail, A. (1994) The effect of feeding frequency on the growth of catfish, Clarias spp. reared in a portable raceway system, Fish Nutrition Research in Asia, Asian Fish. Soc. Spl. Publ., 9: 115-118.

Kungvankij, P., Tiro, L.B., Pudadera, B.J. and Potestas, I.O. (1986) Biology and Culture of Sea Bass (Lates calcarifer), Network of Aquaculture Centers in Asia Training Manual Series No. 3., Food and Agriculture Organization of the United Nation and Southeast Asian Fisheries Development Center.

Lee, S., Hwang, U. and Cho, S.H. (2000) Effects of feeding frequency and dietary moisture content on growth, body composition and gastric evacuation of juvenile Korean rockfish (Sebastes schlegeli), Aquaculture, 187: 399-409.

NICA (1986) Technical Manual for Seed Production of Sea Bass, National Institute of Coastal Aquaculture, Songkhla, Thailand.

Nour, A.A., Mabrouk, H., Omar, E., El Wafa, M.A. and Akkaada, A.A. (1993) Effect of feeding levels and stocking densities on growth performance and feed utilization of grey mullet (Mugil cephalus), Proc. Aquaculture Symposium, Technology and Investment Opportunities, 11-14 April, 1993, Riyadh, Saudi Arabia, pp: 550-559.

NRC (1977) Nutrient requirements of warmwater fishes, National Academy of Science, Washington, DC, $78 \mathrm{p}$.

Parazo, M.M., Avila, E.M. and Reyes Jr., D.M. (1991) Size and weight dependent cannibalism in hatchery-bred sea bass (Lates calcarifer, Bloch), Journal of Applied Ichthyology, 7: 1-7.

Parazo, M.M., Garcia, L.Ma. B., Ayson , F.G., Fermin, A.C., Almendras, J.M.E. and Reyes, D.M. (1990) Sea bass Hatchery Operations. Aquaculture Extension Manual No. 18. Aquaculture Department, Southeast Asian Fisheries Development Center, Iloilo, Philippines.

Pillay, T.V.R. (1990) Sea basses and Seabreams in Aquaculture Principles and Practices, Fishing News Books. Oxford, England, 398-407.

Riche, M., Haley, D.I., Oetker1, M., Garbrecht, S. and Garling, D.L. (2004) Effect of feeding frequency on gastric evacuation and the return of appetite in tilapia Oreochromis niloticus, L' Aquaculture, 234: 657-673.

Rimmer, M.A. and Russell, D.J. (1998) Aspects of the Biology and Culture of Lates calcarifer, In: Tropical Mariculture, S.S. de Silave ed. Academic Press, U.S.A., pp: 449476.

Seenappa, D. and Devaraj, K.V. (1991) Effect of feeding levels on food utilization and growth of catla fry. Fish Nutrition Research in Asia, Asian Fish. Soc. Spl. Publ., 5: 49-54.

Shimeno, S., Shikata, T., Hokosawa, H., Masumoto, T. and Kheyyali, D. (1997) Metabolic response to feeding rates in common carp, Cyprinus carpio. Aquaculture, 151: 371-378.

Silva, C.R., Gomes, L.C. and Brandão, F.R. (2007) Effect of feeding rate and frequency on tambaqui (Colossoma macropomum) growth, production and feeding costs during the first growth phase in cage, Aquaculture, 264: 135-139.

Silva, S.D., Gunasekera, R.M. and Khibiyahetty, C. (1986) Optimum ration and feeding frequency in Oreochromis niloticus young. In: J. L. Mclean, L.B. Dizon and L.V. Hosillos eds, Proc. of the First Asian Fisheries Forum, Manila, Philippines, 26-31 May, pp: 559561.

Tacon, A.G.J. (1993) Feed Formulation and On-Farm Feed Management, In: M.B. New, A.G.J. Tacon and I. Csavas (eds), Farm-Made Aquafeeds, Proc. of the FAO/AADCP. Regional 
Expert Consultation on Farm-made Aquafeeds, 14-18 December 1992, Bangkok, Thailand, pp: 61-74.

Tattanon, T. and Tiensongrusmee, B. (1984) Manual for Spawning of Sea bass, Lates calcarifer, in Captivity, Food and Agriculture Organization of the United Nations, Rome.

Tucker, B.J., Booth, M.A., Allan, G.L., Booth, D. and Fielder, D.S. (2006) Effects of photoperiod and feeding frequency on performance of newly weaned Australian snapper, Pagrus auratus, Aquaculture, 258: 514-520.

Tyler, A.V. and Dunn, R.S. (1976) Ration, growth and measures of somatic and organ condition in relation to meal frequency in winter flounder Pseudopleuronectes americanus with hypothesis regarding population homoeostasis, J. Fish. Res. Brd. Can., 33: 63-75.

Wang, N., Hayward, R.S. and Noltie, D.B. (1998) Effects of feeding frequency on food consumption, growth, size variation, and feeding pattern of age-0 hybrid sunfish, Aquaculture 165: 261-267.

Wang, Y., Kong, L., Li, K. and Bureau, D.P. (2007) Effects of feeding frequency and ration level on growth, feedutilization and nitrogen waste output of cuneate drum (Nibea miichthioides) reared in net pens, Aquaculture (Accepted), AQUA-627602; No. of Pages 7.

Windell, J.T. (1976) Feeding frequency for rainbow trout, Comm. Fish. Farm, 2(4): 14-15. 


\section{Lates calcarifer استجابة إصبعيات القاروص الآسيوي لمعدلات وتزددات تغذية مختلفة، و المستزر عة فى ملوحة البحر الأحمر العالية}

عدنان جميل سلامة و ممدوح علي الحربي

كلبة علوم البحار، جامعة الملك عبدالعزبيز

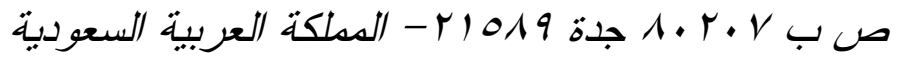
العستخلص. تهدف هذه الدراسة لتطوير برنامج غذائي مناسب

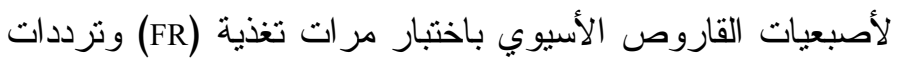

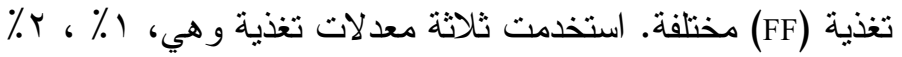

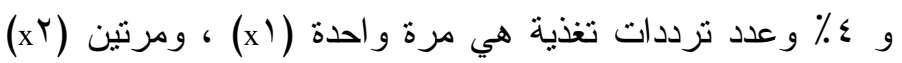

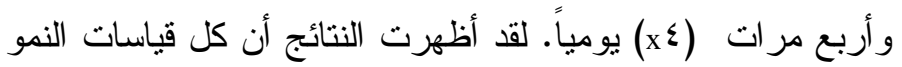

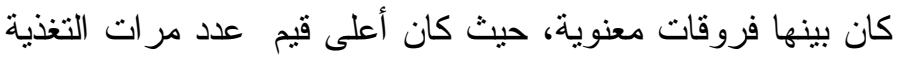

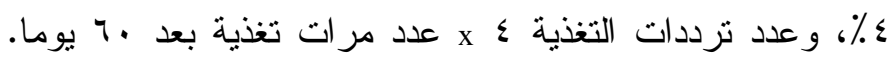

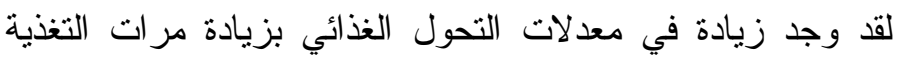

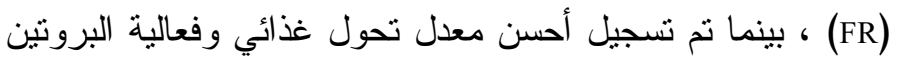

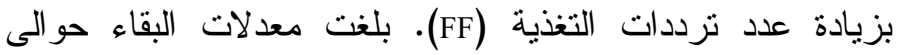

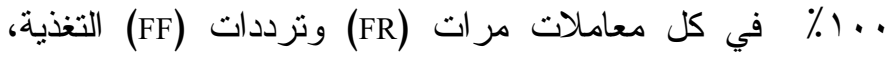

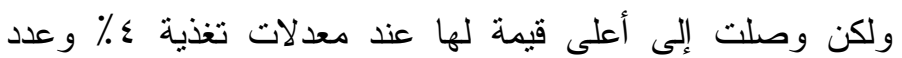

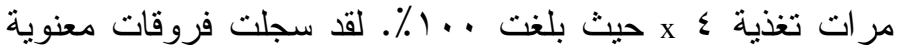

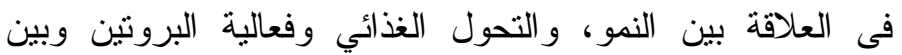

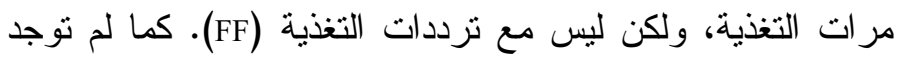

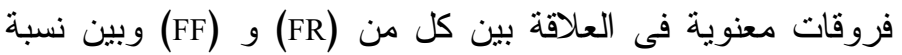

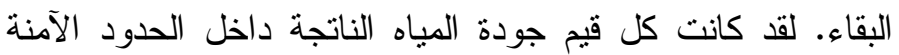
لتربية إصبعيات القاروص الآسيوى. 